\title{
economics-of-security.eu
}

Javier Gardeazabal

\section{Linguistic Polarization and Conflict in the Basque Country}

October 2011

Economics of Security Working Paper 56

This publication is an output of EUSECON, a research project supported by the European Commission's Seventh Framework Programme.

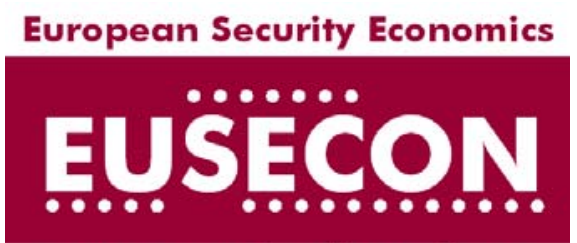

www.economics-of-security.eu

Economics of Security is an initiative managed by DIW Berlin 
Correct citation: Gardeazabal, J. (2011). "Linguistic Polarization and Conflict in the Basque Country". Economics of Security Working Paper 56, Berlin: Economics of Security.

First published in 2011

(C) Javier Gardeazabal 2011

ISSN: 1868-0488

For further information, please contact:

Economics of Security, c/o Department of Development and Security, DIW Berlin - German Institute for Economic Research, Mohrenstr. 58, 10117 Berlin, Germany.

Tel: +49 (0)30 $89789-277$

Email: eusecon@diw.de

Website: www.economics-of-security.eu 
Noname manuscript No.

(will be inserted by the editor)

\title{
Linguistic Polarization and Conflict in the Basque Country
}

\author{
Javier Gardeazabal
}

the date of receipt and acceptance should be inserted later

\begin{abstract}
This paper investigates the relationship between linguistic polarization and conflict in the Basque Country. During the 40 years of Franco's dictatorship the use of the Basque language was banned. Therefore, there may be some linguistic roots underlying the conflict in the Basque Country. We show that at the municipality level, linguistic polarization reduces the level of conflict. This finding is robust to various ways of measuring linguistic and ideological polarization and the inclusion of other covariates. In addition, we find that a high level of the stock of human capital is beneficial for reducing conflict intensity.
\end{abstract}

Keywords Linguistic Polarization, Fractionalization, Terrorism, Conflict.

\section{Introduction}

From an economic point of view, the relationship between ethno-linguistic fragmentation and conflict is important as conflict is thought to be detrimental to economic growth and, therefore, understanding the sources of conflict would help economic development. The available evidence indicates that ethno-linguistic fragmentation is associated with lower quality of institutions and bad economic performance (e.g., Easterly and Levine 1997; Alesina et al. 2003). This evidence can be interpreted as lending support to theories of clashing interest groups (e.g., Esteban and Ray 2008, 2011).

This paper focuses on the relationship between linguistic fragmentation and conflict. Establishing a causal link between linguistic fragmentation and conflict is intricate for several reasons. A first difficulty is measurement. Linguistic diversity manifests when different social groups speak different languages, i.e., society is fragmented into different linguistic groups. Linguistic fragmentation in a country or region can be measured in different ways. A commonly used measure is the index of fractionalization defined as the probability that two randomly chosen individuals belong to different linguistic groups. An alternative way of measuring linguistic fragmentation is the concept of polarization, defined as the distance between the frequency distribution of linguistic groups to the bipolar distribution, which yields the highest level of polarization. A country with two linguistic groups, each group comprising half the population, would be polarized to the highest possible degree, but much less fractionalized. On the contrary, a country like Chad with 131 living languages must necessarily be highly fractionalized, but polarized to a lesser extent. It turns out that using fractionalization or polarization measures of linguistic diversity may result in different causal inferences. For instance, Montalvo and Reynal-Querol (2005) provide evidence suggesting

Javier Gardeazabal

Departamento de Fundamentos del Análisis Económico II, Universidad del País Vasco, Lehendakari Aguirre 83, 48015 Bilbao, Spain. E-mail: javier.gardeazabal@ehu.es 
that ethno-linguistic polarization increases the likelihood of internal armed conflict while ethno-linguistic fractionalization does not.

When society is divided in two demographic groups, fractionalization and polarization indexes turn out to be linearly dependent and there is no difference between using one or the other as far as the statistical inference is concerned; see Montalvo and Reynal-Querol (2005). Due to this linear relationship between polarization and fractionalization, the two concepts can be used interchangeably. Hereinafter, when referring to previous works we will use the specific term used by the authors, which may create some confusion as some use fractionalization and others use polarization.

A second difficulty arises from the nature of conflict itself. Conflict can manifest itself in different forms, through strikes, demonstrations, riots, guerrilla warfare, terrorism or civil war. Conflict can be thought of as a latent variable on which researchers observe measurements such as a binary indicator of participation in an armed conflict, the number of casualties in a civil war or the number of terrorism events. It comes as no surprise that alternative conflict measurements result in different causal effects. Laitin (2000) reports evidence suggesting that language grievances are not associated with group violence, while Abadie (2006) finds that linguistic fractionalization is a determinant of terrorism risk.

A third difficulty appears in distinguishing between linguistic and ethnic groups: ethnic groups are often defined by their language. Therefore, when researchers try to assess the effect of ethnic and linguistic fragmentation on conflict, there is no clear-cut distinction between the contribution of ethnic and linguistic diversity to conflict. This is probably why many researchers focus on ethno-linguistic fractionalization, instead of considering both separately. A notable exception is Wimmer and Cederman (2009), who found that, once ethnic fractionalization is controlled for, linguistic fractionalization is not a significant determinant of armed conflict. To the extent that some ethnic groups are defined by their language, ethnic fractionalization might capture some linguistic fractionalization and, hence, may take some explanatory power away from linguistic fractionalization.

In this paper, we study the relationship between linguistic polarization and conflict using municipality level data for the Basque Country. As we will argue below, the Basque Country constitutes an especially interesting and appropriate case study for the issue at hand. Contrary to what theory, intuition and the cross-country evidence suggest, our findings indicate that linguistic polarization in the Basque Country actually reduces the level of conflict. However, the evidence presented in the following sections does not contradict previous empirical evidence nor falsifies available theory. Modern theories of ethnic conflict suggest that polarization induces conflict (e.g., Esteban and Ray 2008). How can linguistic polarization in the Basque Country reduce the level of conflict? An interpretation of this result might be that greater levels of linguistic polarization open a channel through which Basque speakers can manifest their nationalism by using their language regularly. Linguistic polarization could serve as an escape valve for conflict, reducing the probability of engaging in terrorist activities. When polarization is low, however, it is more difficult to manifest nationalism through the use of the Basque language, either because most or only a few people speak Basque.

The level of disaggregation of our study is important. While cross-country differences in ethno-linguistic polarization might indicate the existence or absence of a potential source of conflict, ethno-linguistic polarization at the municipal level indicates group mixing which might actually be beneficial in reducing the level of conflict. To make the argument more precise, consider the example of a society with two demographic groups, each containing half of the population. Polarization in this society would be equal to 1 , its maximal value. Suppose now that people in this society live in two towns. Further suppose that each town is home to one demographic group. In this case, despite the fact that overall polarization is 1 , within-town polarization is 0 , its minimal value. Alternatively, suppose now that each town holds half of each demographic group. Then, both overall and within town polarization would be 1 . In the former case, when each group lives in a town, there is no group mixing while in the second case group mixing is 
complete. The mixing case can occur only if the two groups can live together in the same town. It seems intuitive to think that, in this simple example, the overall level of polarization could be an indicator of conflict while the within-town level of polarization can be an indicator of peace.

The rest of the paper is organized as follows. Section 2 describes the case study analyzed in this paper and explains the identification strategy used to make statistical inferences about the relationship between linguistic polarization and conflict. Section 3 identifies some potential confounding factors in our analysis. Section 4 describes the data set used, which is described further in the Appendix. Section 5 reports the empirical results and Section 6 summarizes and discusses the main findings.

\section{The case}

In this paper, we conduct what we think is an interesting case study of the relationship between linguistic fragmentation and conflict using data from the Basque Country. ${ }^{1}$ Basque and Spanish are the two official languages in the Basque Country. As the Basque Country is a bilingual community, we need not distinguish between linguistic polarization and fractionalization.

Our case study exhibits some features that make it especially worth exploring. The more salient feature of this case study relates to the linguistic roots of the conflict. Until the middle of the nineteenth century, Basques had a peaceful relationship with the Spanish Crown. After the Carlists Wars, when the Spanish government revoked some of the Basque Country's autonomy, Basques began demanding more rights of self-governance, but it would not be until a century later, in 1968, when the Euskadi Ta Askatasuna (ETA) terrorist organization would produce its first victim. After the Spanish Civil War, during Franco's dictatorship (1936-1975), the use of the Basque language was banned and repressed. Therefore, it is reasonable to think that after a long period of repression, the linguistic issue in the Basque Country could be a source of conflict.

Social cleavage theory is another reason to blame linguistic issues for the conflict in the Basque Country. Desmet et al. (2009) provide evidence indicating that fractionalization measures based on deep linguistic cleavages dating back thousands of years are better predictors of conflict than more superficial ones dating back only hundreds of years ago. As Basque is the last remaining pre-Indo-European language in Western Europe and hence very different from Spanish, this linguistic distance between the two main languages spoken in the Basque Country can be considered as a predictor of conflict. Other bilingual regions in Spain, Catalonia and Galicia, constitute prima facie cases of this theory. Catalan and Galician share a much closer ancestor with Spanish: Latin. While Catalonia and Galicia also have had nationalistic demands, they have not experienced a terrorist conflict comparable to the Basque.

Another interesting feature of our case study is the ethno-linguistic cut of the population under study. Ethno-linguistic diversity in the Basque Country has a strong linguistic basis. The term Euskaldun is used in Basque language to refer to both a Basque person and a Basque speaker, which suggests that a Basque person is someone who speaks Basque.

It has long been argued that Basque people were a genetic isolate. Their genomes have been considered to be the most direct descendants of those who dwelt in Europe before the spread of agriculture (e.g., Dupanloup et al. 2005). However, recent research based on genome-wide analysis shows that Basques are not genetically different from other populations in Spain (e.g., Laayouni et al. 2010). Therefore, the difference between the two ethno-linguistic groups in the Basque Country is fundamentally linguistic and does not have a genetic component.

\footnotetext{
1 Henceforth, we use the term Basque Country to refer to the Spanish autonomous region Comunidad Autónoma Vasca (Euskadi in Basque) comprising the provinces of Alava, Guipúzcoa and Vizcaya (Araba, Gipuzkoa and Bizkaia). Basque is also spoken in Navarre in Spain and the Northern Basque Country in France.
} 
A further interesting feature of our case study is the absence of religious motivation. Recent research shows that religious factors are conflict determinants (e.g., Baseadau et al. 2011; Esteban and Mayoral 2011). However, most Basques are Roman Catholic regardless of their linguistic group. As there are no religious differences between linguistic groups, religion cannot be a confounding factor in our analysis.

Our identification strategy relies on the geographical variation in linguistic polarization across municipalities. The Basque Country exhibits a fairly high geographical heterogeneity in Basque language use, providing a source of variability in linguistic polarization. Linguistic polarization is bound to change very little within a short period. ${ }^{2}$ However, as a result of the rapid rise in the number of Basque speakers after its decades-long suppression as well as demographic movements explained below, linguistic polarization has experienced a relatively large change during the sample period analyzed providing an additional source of variability difficult to observe in any other region or country during an equivalent period of time.

Variability in linguistic polarization across space and time is not sufficient to identify a causal link with conflict. Should these sources of variability be exogenous, identification would be obtained. However, the possibility exists that these sources of variability in linguistic polarization might not be exogenous. Migration patterns might invalidate the exogeneity assumption. During our period of analysis, there was a sizeable inflow of immigrants, mostly from Spanish-speaking countries, to the Basque homeland. If these immigrants chose destinations with perceived less conflict, changes in linguistic polarization would not be exogenous. Immigrants from other Spanish regions and migrants between Basque municipalities might also choose their residences conditional on the level of conflict. Furthermore, it is well known that many people, particularly entrepreneurs, have abandoned the Basque Country over recent decades owing to the threat of terrorism and extortion. These demographic movements might affect the level of linguistic polarization and therefore create a reverse causality problem. This potential endogeneity problem is accounted for in the estimation by using dynamic panel data techniques that allow us to use lagged levels and differences of the endogenous variables as instruments.

\section{Potentially confounding factors}

The analysis also takes into account the effect of other covariates which could otherwise have a confounding effect on the relationship between linguistic polarization and conflict. In particular, we control for ideological, economic and demographic factors.

Ideological or political differences can certainly be potential sources of conflict. However, establishing a causal link between these variables is problematic. First of all, ideological differences are difficult to measure. Party vote shares might serve the purpose of measuring the degree of ideological polarization or fractionalization. However, ideological polarization measured this way limits the analysis to democratic countries. In the case of the Basque Country, we can account for political polarization using party vote shares at the municipal level. Secondly, as the number of political parties is greater than two, political polarization and fractionalization are not linearly related as it was the case for linguistic polarization. In this case, we cannot use polarization and fractionalization as synonymous. Thirdly, another reverse causality problem may appear if violence plays a role in shaping people's ideology and therefore their political choices. Available evidence for the United States, Israel and Spain suggests that vote shares are affected by terrorist activity (Karol and Miguel 2007); Gould and Klor 2010; Gardeazabal 2010). Hence, both linguistic and political polarization can be considered as endogenous explanatory variables. As mentioned above, the dynamic panel data methodology can account for this endogeneity problem.

\section{[Insert Table 1 near here]}

\footnotetext{
2 Campos and Kuzeyev $(2007,2011)$ find that 26 transition economies experienced a relatively important change in ethnic fractionalization over a two decades period. However, linguistic fractionalization remained fairly constant over that period.
} 
Arguably, the Left/Right and Nationalist/Non-Nationalist cleavages might have different effects on conflict. These effects cannot be identified when using individual party vote shares to measure political polarization and fractionalization. Therefore, we also measure political polarization along the Left/Right and Nationalist/Non-Nationalist ideological dimensions. This is possible because political parties in the Basque Country cover all Left/Right and Nationalist/Non-Nationalist combinations as illustrated in Table 1. Since the conflict in the Basque Country is a nationalist one, it seems reasonable to think that polarization along the Nationalist/Non-Nationalist ideological cleavage should explain some of the conflict. However, polarization along the Left/Right dimension might also contribute to explaining the conflict. The two main parties in Spain, Partido Socialista and Partido Popular place the terrorist conflict in the Basque Country among the top items on their political agendas and often approach it from different perspectives and blame each other in this regard.

Cross-country studies suggest that economic factors are not significant determinants of conflict (Abadie 2006; Piazza 2006). However, economic adversity in the form of poverty or inequality can induce conflict and violence if they align with ethnic, religious or ideological cleavages (Kanbur 2007; Sen 2008). The Basque Country does particularly well in economic terms and economic issues do not seem to be the root source of conflict. Nevertheless, in order to be on the safe side, our empirical analysis also accounts for economic factors. In particular, we use the unemployment rate and an index of economic activity at the municipality level to account for the potential effect of economic conditions on conflict.

There is another demographic factor that might have some bearing in the relationship between linguistic polarization and conflict in the Basque Country: the stock of human capital of the Basque Country population. The relationship between the stock of human capital and violent conflict has been analyzed elsewhere. For the Israeli-Palestinian conflict, Krueger and Maleckova (2003) report evidence indicating that Palestinian terrorists tend to be better educated than the average Palestinian. In particular, engineers are overrepresented among other Islamists terrorist (e.g., Gambetta and Hertog 2009). Using data from the Israeli-Palestinian conflict, Benmelech et al. (forthcoming) likewise find that higher unemployment rates allow terrorist organizations to recruit better educated terrorists. Unfortunately, we have no access to data on the level of educational attainment among ETA terrorists, however, anecdotal evidence suggests that this is also the case in the Basque Country. In October 13th, 1997, Ibon Gogeaskoetxea (B.A. in Journalism) and Eneko Gogeaskoetxea (B.Sc. in Engineering) killed a policeman when he foiled a plot to stage a terrorist attack during the opening ceremony of the Guggenheim Museum in Bilbao by King Juan Carlos on October 18th. However, the stock of human capital of a municipality may not be related with the stock of human capital of a particular individual who self-selects to be a terrorist. The relationship between the stock of human capital of a society and the level of conflict is important as educational policy might have a beneficial effect on conflict depending on the sign of this relationship. Previous research into this policy effect suggests that education can have constructive and destructive impacts on conflict (e.g., UNICEF 2000).

Another confounding factor could be the degree of urbanization. This is particularly important because rural municipalities tend to have a large size of the Basque linguistic group. Hence, in order to control for the potential effect of urbanization, we include population in our regressions.

\section{[Insert Figure 1 near here]}

Another confounding factor could arise from the fact that this empirical analysis is carried out within a time interval when the overall level of conflict in the Basque Country was decreasing, see Figure 1. The existence of this downward trend in the dependent variable makes it non-stationary, posing a problem for statistical inference. Our empirical analysis controls for this downward trend by including period-specific dummy variables. These period-specific dummies have the potential to capture all those municipalityinvariant factors having a common effect on all municipalities, such as political instability or anti-terrorist policy. Cross-country empirical studies suggest that political instability is a significant determinant of 
conflict (e.g., Reynal-Querol 2002). For the Basque Country case, the level of political instability across municipalities should be the same. However, political instability at the beginning of the sample period was surely high and then fell to low levels by the end of the sample. Anecdotally, Tejero's attempted coup d'état on February 23th, 1981, would be unthinkable by the end of the sample. Accordingly, the overall level of conflict has decreased over the sample period analyzed.

In addition to a downward trend, the overall level of conflict in the Basque Country has experienced ups and downs, that is, deviations from the trend. In our empirical analysis, these fluctuations are captured by using a dynamic panel data modeling strategy which captures the oscillating pattern of the conflict measurement.

Our empirical evidence shows that political fractionalization and polarization do have a significant effect on the level of conflict. According to our findings, greater political polarization is associated with higher levels of conflict. Political polarization along the Left/Right dimension also correlates positively with conflict; however, political polarization along the Nationalist/Non-nationalist dimension is negatively correlated with conflict intensity. Another interesting finding is the beneficial effect of a larger stock of human capital on conflict, suggesting that education in the Basque Country might have had a constructive type of effect on conflict. Finally, some of the economic indicators used in the empirical analysis turn out to be significant.

\section{The data set}

The data set is an unbalanced panel of 250 municipalities located in the Basque Country over an 18-year period (1989-2006) with annual frequency. ${ }^{3}$ The variables included in our data set are described below.

Our outcome variable is terrorism activity measured by the annual number of assassinations in each municipality. Of course, the number of terrorist assassinations is only a proxy measure of the latent level of conflict. Although admittedly a proxy, there are reasons to believe that the number of terrorist assassinations in a municipality may actually be a good indicator of the latent level of conflict in that municipality. It is well known that ETA targets as victims law enforcement forces, politicians and entrepreneurs through its militant network. ETA's network informs the actual perpetrators of the location and habits of targeted victims. Therefore, the observation of an assassination can be taken as an indication of the existence of a terrorist network within the area. Under these circumstances, geographical dissemination of assassinations indicates network density which in turn signals conflict intensity.

A zero number of assassinations in a municipality does not imply that there is no conflict in a given town. ETA's network orchestrates physical and psychological violence on its victims, see Martín-Peña et al. (2010). This violence ranges from coercion and extortion at the lower end to kidnappings and murder at the higher end. According to this scale of violence, the number of assassinations only records events at the upper side of the scale. This is also consistent with the latent variable interpretation of conflict, which suggests that a conflict indicator such as the annual number of assassinations in each municipality records instances when conflict is above a certain fairly high threshold.

As ETA militants living in a town may actually follow and report on the habits of targeted people in neighboring towns, the number of assassinations might be considered a measurement with error. We have constructed an estimate of the latent level of conflict as a weighted average of assassinations in neighboring towns to mitigate this error. The resulting conflict index assigns positive values to towns with zero assassinations but neighboring towns with positive number of assassinations. To the extent that ETA's network may operate from nearby localities, our spatially weighted measure of conflict might be a better indicator of conflict than the raw number of assassinations.

\footnotetext{
3 There are 251 municipalities in the Basque Country. We excluded Ziortza-Bolibar because of lack of data.
} 
This spatially weighted index of the latent level of conflict is estimated as follows. The index value for municipality $i$ in year $t, y_{i t}$, is computed as

$$
y_{i t}=\sum_{j=1}^{J} k\left(d_{i j}\right) n_{j t}
$$

where $J$ is the number of municipalities, $n_{j t}$ is the actual number of assassinations in municipality $j$ in period $t, k\left(d_{i j}\right)$ is a weight that depends on the distance between municipalities $i$ and $j, d_{i j}$. The weighting function used is Epanechnikov's kernel

$$
k\left(d_{i j}\right)=\frac{3}{4}\left(1-\left(\frac{d_{i j}}{h}\right)^{2}\right) I\left(\frac{d_{i j}}{h} \leq 1\right),
$$

where $h$ is the bandwidth parameter and $I(a)=1$ if $a$ is true and zero otherwise. Distances between municipalities are computed using the spherical law of cosines. The bandwidth parameter, $h$, is the radius of the circle defining neighbor municipalities. Thus, if the distance between municipalities $i$ and $j$ is less than $h$, the indicator function takes the value of one and the number of assassinations in municipality $j$ enters the index value for municipality $i$. However, the actual value of the weight is heavier, the closer municipalities are to one another. This spatial kernel measure of conflict is smoother than the simple count of the yearly number of assassinations. It assigns positive values to municipalities which have no assassinations but are geographically close to other municipalities where there were killings.

This spatial conflict index does not account for exposure to conflict. That is, it does not take into account the size of the municipality. If targeted victims were selected randomly, more populated municipalities would be the venues of greater numbers of assassinations because the probability of observing an assassination in a highly populated municipality would be larger. We divide our index by thousands of people in each municipality to account for exposure to conflict. Figure 2 shows the variation of the spatial index of conflict across municipalities.

\section{[Insert Figure 2 near here]}

Data on all the explanatory variables were available with different frequencies. We have constructed an annual data set by interpolating several variables. Detailed definitions of all variables and interpolation method are provided in the appendix.

Our data set records the number of people belonging to each linguistic group for each town in the Basque Country. Linguistic groups are defined according to three classification methods: mother tongue, language spoken at home and Basque knowledge. For instance, using the mother tongue taxonomy, people are classified into four categories: Basque, Spanish, both and other. The 'both' category is not a third linguistic group, as treating it as another linguistic group would artificially bias our measures of linguistic polarization. Almost all Basque speakers are able to speak Spanish, while the opposite is not true, so we merged the 'both' and 'Basque' categories. On the other hand, the 'other' category is always very small, so we can effectively think of a two-class taxonomy. Therefore, the difference between fractionalization and polarization is irrelevant.

The mother tongue taxonomy of linguistic groups does not perfectly fit the purpose of our analysis. For an individual, their mother tongue certainly is exogenous, but as argued above, linguistic polarization at the municipal level need not be exogenous. In addition, what is important for our analysis is whether people identify themselves with a linguistic group. Over recent decades, the number of people who speak Basque has increased greatly and many people whose mother tongue is Spanish have learned Basque at school. An indication of this fact is that the correlation between linguistic polarization measured using the mother tongue and Basque knowledge taxonomies is only 0.35. Note that linguistic groups defined by Basque knowledge might result in an additional endogeneity source of linguistic polarization. 
[Insert figure 3 near here]

[Insert figure 4 near here]

[Insert figure 5 near here]

[Insert Table 2 near here]

The index of linguistic (political) polarization used is Reynal-Querol (2002) $R Q=1-\sum_{i=1}^{N}\left(\frac{0.5-\pi_{i}}{0.5}\right)^{2} \pi_{i}$ where $\pi_{i}$ is the proportion of people who belong to the linguistic (political) group $i$, and $N$ is the number of groups. As discussed previously, the data set exhibits a remarkably large variability of linguistic polarization across municipalities. Table 2 shows that linguistic polarization ranges from 0 to 1 according to all three taxonomies. Figure 3 plots linguistic polarization for all municipalities as of 2006 as a function of the size of the Basque mother tongue linguistic group. The figure documents the rather large variability in linguistic polarization, which ranges from 0.07 to 1 , thus covering almost the entire unit interval. It also shows that maximal polarization corresponds to cases where the fraction of Basque linguistic group is about half the population. Had there been only two linguistic groups, circles on the graph would be on top of a curve defined by a quadratic function and the maximum would be at a size of the Basque linguistic group equal to 0.5. This figure also shows that as the size of the Basque linguistic group increases, polarization increases if the size is below, roughly, 0.5 and decreases above that point. In fact, the size of the Basque linguistic group has changed over time. During our sample period, on average, the size of the Basque linguistic group has increased (decreased) in towns with Basque linguistic groups whose size is below (above) 0.5. As a result, the average linguistic polarization has increased from 0.43 in 1986 to 0.60 in 2006. This upward trend in linguistic polarization is illustrated in Figure 4. In addition, Figure 5 shows how linguistic polarization varies across municipalities.

\section{[Insert Figure 6 near here] \\ [Insert Figure 7 near here]}

We measure ideological fragmentation using data from parliamentary elections. In particular, we use party vote shares from Spanish General Elections. Figure 6 illustrates the persistence of political polarization over time. Variability over time in political polarization does not seem to provide an avenue for identifying a causal effect on conflict. Fortunately, political polarization exhibits high variability across municipalities, as illustrated in Figure 7. Political polarization measured using individual party vote shares ranges from 0.34 to 1 . Political polarization on the Left/Right dimension ranges from 0.3 to 1 and in the Nationalist/Non-Nationalist dimension from 0 to 1 . Political fractionalization is measured using the Herfindahl-Hirschman Index, $F R A C=1-\sum_{i=1}^{N} \pi_{i}^{2}$. Political fractionalization measured using individual party vote shares ranges from 0.17 to 0.99 . This variability in political polarization and fractionalization provides a source of fluctuation to identify the causal effect of political fractionalization and polarization on our conflict measure.

In addition to ideological factors, we also control for the stock of human capital, proxied by the fraction of people with academic degrees (Four and five-year licences and Doctoral degrees). This variable also exhibits a wide range from 0 to 0.28 . We use the rate of unemployment to control for economic fluctuations. The unemployment rate, which is very persistent over time, likewise exhibits a wide range of variation between municipalities from 0 to 0.36 . We also use another measure of economic performance, the number of financial establishments per thousand people, which indicates the economic relevance of a municipality but exhibit less cyclical fluctuations than unemployment. This indicator ranges from 0 to 14.3 .

\section{Empirical results}

The dynamic panel data model specification is

$$
\phi(L) y_{i t}=X_{i t}^{\prime} \beta+\eta_{i}+\mu_{t}+\varepsilon_{i t},
$$


where $\phi(L)=1+\phi_{1} L+\ldots+\phi_{p} L^{p}$ is a $p$-th order polynomial in the lag operator $L$; $y_{i t}$ is the value of the spatial conflict index for municipality $i$ in year $t ; X_{i t}$ is a vector of explanatory variables which includes linguistic polarization and other covariates; $\eta_{i}$ is a municipality specific unobserved effect; $\mu_{t}$ is a period-specific unobserved effect and $\varepsilon_{i t}$ is a zero mean random disturbance. The GMM methodology proposed by Arellano and Bover (1995) and Blundell and Bond (1998) is used to estimate this model.

[Insert Table 3 near here]

We report baseline regressions in Table 3 . In all cases, the spatially weighted conflict index uses a bandwidth of 10 kilometers and a full set of period-specific dummies. Column (1) in Table 3 reports a fixed-effect regression of the spatial conflict index on linguistic polarization (Basque knowledge taxonomy) and political polarization. The coefficient estimate on linguistic polarization is negative and significant, while the coefficient on political polarization is positive and insignificant. These results are likewise set out in column (2) which includes a significant lagged value of the spatial conflict index. We report GMM estimates from this point on as fixed-effect estimates of dynamic panel data models are known to be inconsistent.

Our empirical specification allows for two characteristics of the data. First, columns (3) to (6) include three conflict index lags. The first two lags of the conflict index are statistically significant in all cases, while the third lag is retained as the residuals exhibit autocorrelation if omitted. Note that the coefficient estimates of the lags of the conflict index alternate in sign, which indicates that the dependent variable exhibits some oscillatory pattern. Second, in all cases a full set of period-specific dummy variables was included. These dummies, not reported in the tables, turn out to be significant and capture the nonstationary nature of the dependent variable.

Column (3) treats linguistic and political polarization as exogenous, that is, the estimation method uses moment conditions which make use of the assumed orthogonality between these variables and the disturbance. Columns (4) to (6) report estimates that account for the feasible endogeneity of linguistic and political polarization by using moment conditions which make use of the orthogonality between lagged values of these variables and the disturbance term. Linguistic polarization is significant and has negative coefficient estimate in all cases. Political polarization has a positive coefficient estimate and is marginally significant in column (4). In columns (5) and (6) we include alternative measures of political polarization and fractionalization. Column (5) suggests that political polarization along the Left/Right and Nationalist/NonNationalist dimensions are significant determinants of conflict. Polarization on the Left/Right front seems to contribute to conflict in the Basque Country, while polarization along the Nationalist/Non-Nationalist axis is beneficial, reducing the level of conflict. A feasible interpretation of this finding is that political clashes in the Nationalist/Non-Nationalist front may substitute for other forms of conflict. What is important is that, even after controlling for political polarization along the nationalist front, linguistic polarization tends to reduce the level of conflict.

Finally, political fractionalization turns out to be significant and has a negative coefficient estimate in column (6). This might be interpreted as meaning that as all political ideologies tend to be equally represented (fractionalization tends to its maximal value), the intensity of conflict diminishes.

[Insert Table 4 near here]

Table 4 reports similar regressions, this time controlling for other covariates, such as population, the fraction of people holding an academic degree, the unemployment rate and the number of financial establishments per thousand people. The stock of human capital measured by the fraction of people holding an academic degree is significant and has negative sign in columns (2) and (5). This evidence suggests that education plays a beneficial role in the Basque Country conflict. Population and the unemployment rate are statistically insignificant in determining conflict intensity. Finally, economic relevance of a municipality, as measured by the number of financial establishments in per capita terms is significant and has negative sign in column (5). This finding indicates that good economic performance alleviates conflict intensity. 
[Insert Table 5 near here]

Table 5 reports the same regressions as in Table 4 including political fractionalization instead of political polarization. Linguistic polarization remains significant in all cases. The main difference with respect to previous results is that political fractionalization has a negative sign, indicating that more fractionalization actually reduces the level of conflict. Therefore, political fractionalization and polarization measures appear to have opposite effects on conflict.

[Insert Table 6 near here]

Further robustness tests are reported in Table 6 . The beneficial effect of linguistic polarization remains significant across linguistic taxonomies in columns (1) to (3). However, when the mother tongue and language used at home taxonomies are entered, significance levels are higher. As a final robustness test, columns (4) and (5) repeat some of the previous regressions using an estimate of the conflict index computed with a bandwidth of 20 kilometers. The results do not change qualitatively.

\section{Conclusions and discussion}

This research leads to three main findings. First, the empirical evidence reported in this paper suggests that linguistic polarization in the Basque Country reduces the level conflict. Second, political polarization along the Left/Right dimension has positive effect on conflict while political polarization along the Nationalist/Non-Nationalist dimension has a negative effect on conflict. Third, the stock of human capital in a municipality seems to have a negative effect on conflict.

A caveat worth mentioning at this point is that all the evidence reported herein relies on the quality of our spatially weighted conflict index. Should this index be an imperfect measurement of the latent level of conflict at the municipality level, our inferences would be invalid. Provided we meet this requirement, our first finding, the beneficial effect of linguistic polarization on conflict requires an explanation, as it is apparently at odds with previous results found in the literature.

Note that the beneficial effect of linguistic polarization at the municipality level is perfectly compatible with the Basque conflict having a linguistic root. Our reading of the results is as follows. Linguistic, or ethnolinguistic polarization are sources of conflict; however when someone looks at the linguistic polarization at a sufficiently fine level of disaggregation, polarization indicates group mixing, which in fact indicates that different groups can live together peaceably. As argued above, linguistic polarization can serve as an escape valve for conflict, reducing the probability of engaging in violent activities. When linguistic polarization is high, Basque speakers can use their language to manifest their nationalism, while this is not possible when linguistic polarization is low.

In addition, as argued in the introduction, our analysis has been carried out during a time interval where the overall level of conflict in the Basque Country has been decreasing. This time-wise decline in the intensity of conflict was accounted for empirically by using period-specific dummies that capture all the effects common to all municipalities. Therefore, while we find some beneficial effect of linguistic polarization, this might not be responsible for the overall decrease in the level of conflict, which is probably induced by period-specific unobserved effects.

Another finding that requires further comments is the role of the stock of human capital in reducing the level of conflict. This is not the first time education has been found to have a significant effect in reducing conflict. Azam and Thelen (2008) report cross-country evidence in line with our finding. According to UNICEF (2000), education can have constructive or destructive effects on conflict-prone regions. Education can be counterproductive for conflict if administered unevenly among ethnic or linguistic groups, or used as a weapon in cultural repression by manipulating history or textbooks. In the Basque Country case, all people have access to public education which is taught both in Basque and Spanish at the primary, 
secondary and post-secondary levels. Thus, our evidence indicates that education policy in the Basque Country must have been of the constructive type.

The evidence presented in this paper suggests that linguistic polarization at the municipal level is beneficial for reducing conflict. As this is a case study limited to the Basque Country experience, our conclusions may not be extrapolated to other cases. Ideally, further evidence from other conflict regions could provide external validity to the results reported here.

Acknowledgements I would like to thank Alberto Abadie, Jean Paul Azam, Manuel Bagues, Raul Caruso, Cruz Angel Echevarría, Martin Gassebner, Esteban Klor, Jitka Maleckova and Todd Sandler for their helpful comments. My gratitude also to Manuel Bagues and Asier Minondo for providing me with electoral and geographical data and Ana Carmen Díaz Mendoza for her able research assistance. Financial support from the 7th Framework Programme of the European Commission through project EUSECON 218105 and the Spanish Ministry of Science and Innovation through grant ECO2009-09120 is gratefully acknowledged.

\section{Appendix: Variable definition and interpolation}

- Terrorist assassinations. Annual number of terrorist assassinations for each municipality. Source: Asociación de Victimas del Terrorismo.

- Electoral data. Number of valid votes for each party: Partido Popular (PP), Partido Socialista Obrero Español (PSOE), Izquierda Unida (IU), Centro Democrático y Social (CDS), Partido Nacionalista Vasco (PNV), Herri Batasuna (HB), Eusko Alkartasuna (EA) and Aralar. The Left/Right classification is: Left (PSOE, IU, HB, EA, Aralar) Right (PP, CDS, PNV). The Nationalist/Non-Nationalist classification is: Nationalist (PNV, HB, EA, Aralar) Non-Nationalist (PP, PSOE, CDS, IU). Source: Spanish Ministerio del Interior.

- Linguistic taxonomy based on mother tongue. The first language learned in infancy up until the age of three, distinguishing between children who were exposed only to Basque in their early infancy, those who only learned Spanish, those who were exposed to both Basque and Spanish almost simultaneously and finally, those children whose mother tongue was neither Basque nor Spanish. Raw data on the number of people in each category for each municipality transformed into proportions of population in each category. Source: EUSTAT.

- Linguistic taxonomy based on language spoken at home. The language most frequently spoken within the household. The same categories as used for Mother Tongue are admitted: Basque, Spanish, both or other. Raw data on the number of people in each category for each municipality transformed into proportions of population in each category. Source: EUSTAT.

- Linguistic taxonomy based on Basque knowledge. There are three levels of Basque knowledge: Basque speakers, those people whose mother tongue is Basque and who understand and speak it well; almost-Basque speakers, those whose mother tongue is Spanish or another language except Basque and who understand and speak Basque well and whose everyday spoken language at home is Basque; non-Basque speakers are those whose mother tongue is Spanish or a language other than Basque and who do not speak Basque at all and neither understand nor read it well. Raw data on number of people in each category for each municipality. We added the number of people in the Basque and Almost-Basque speakers categories into a single one. The data then were transformed into proportions of population in each category. Source: EUSTAT.

- Population. Number of inhabitants of each municipality in a given year. Source: EUSTAT.

- Unemployment rate. The number of employed and unemployed people are added up to obtain an estimate of the active labor force. Then the unemployment rate is computed as the ratio of unemployed people to the active population. Source: EUSTAT.

- Fraction of people holding an academic degree. The proportion of people holding an academic degree as a fraction of population. Academic degrees include four and five-year licences and Doctoral degrees. Source: EUSTAT.

- Number of financial establishments. The raw number was divided by thousands of people. Source: EUSTAT.

- Latitude and Longitude coordinates. In degrees, minutes and seconds and then transformed into radians.

- Distance between municipalities. Computed from geographical coordinates using the spherical law of cosines.

- Interpolation. The procedure used for interpolation is as follows. Suppose we observe $x_{t}$ and $x_{t+s}$ with $s \geq 2$, then for $j=1, \ldots, s-1$ we compute $x_{t+j}=x_{t}+j\left(\frac{x_{t+s}-x_{t}}{s}\right)$. All variables interpolated are stocks. Table 7 lists the variables in column (1), the dates for which a particular variable is available in column (2) and the estimation sample after interpolation in column (3).

[Insert Table 7 near here] 


\section{References}

Abadie, A. (2006). Poverty, political freedom, and the roots of terrorism. American Economic Review Papers and Proceedings, 96(2), 50-56.

Alesina, A., Devleeschauwer, A., Easterly, W., Kurlat, S., \& Wacziarg, R. (2003). Fractionalization. Journal of Economic Growth, 8(2), 155-194.

Arellano, M., \& Bover, O. (1995). Another look at the instrumental variable estimation of error-components models. Journal of Econometrics, 68(1), 29-51.

Basedau, M., Strüver, G., Vüllers, J., \& Wegenast, T. (2011). Do religious factors impact armed conflict? Evidence from Sub-Saharan Africa. GIGA Working Paper 168. Hanburg, Germany.

Benmelech, E., Berrebi, C., \& Klor, E. F. (forthcoming). Economic conditions and the quality of suicide terrorism. Journal of Politics, .

Blundell, R., \& Bond, S. (1998). Initial conditions and moment restrictions in dynamic panel data models. Journal of Econometrics, 87(1), 115-143.

Campos, N., \& Kuzeyev, V. (2007). On the dynamics of ethnic fractionalization. Journal of Political Science, 51(3): 620-639.

Campos, N., Saleh, A., \& Kuzeyev, V. (2011). Dynamic ethnic fractionalization and economic growth. Journal of International Trade and Economic Development, 20(2), 129-152.

Dupanloup, I., Bertorelle, G., Chikhi, L., \& Barbujani, G. (2004). Estimating the impact of prehistoric admixture on the genome of Europeans. Molecular Biology and Evolution, 21(7), 1361-1372.

Desmet, K., Ortuño-Ortín, I., \& Wacziarg, R. (2009). The political economy of ethnolinguistic cleavages. NBER Working Papers 15360. Cambridge, MA: NBER.

Easterly, W., \& Levine, R. (1997). Africa's growth tragedy: policies and ethnic divisions. Quarterly Journal of Economics, 112(4), 1203-1250.

Esteban, J., \& Ray, D. (2008). On the salience of ethnic conflict. American Economic Review, 98(5), 2185-2002. Esteban, J., \& Ray, D. (2011). Linking conflict to inequality and polarization. American Economic Review, 101(4): 1345-74.

Esteban, J., \& Mayoral, L. (2011). Ethnic and religious polarization and social conflict. Barcelona Economics Working Papers 528.

Gambetta, D., \& Hertog, S. (2009). Why are there so many engineers among Islamic radicals? European Journal of Sociology, 50(2), 201-230.

Gardeazabal, J. (2010). Vote shares in Spanish general elections as a fractional response to the economy and conflict. Economics of Security Working Paper Series 33, DIW Berlin, German Institute for Economic Research. Gould, E., \& Klor, E. (2010). Does terrorism work? The Quarterly Journal of Economics, 125 (4), 1459-1510. Kanbur, R. (2007). Poverty and conflict: the inequality link. Coping with Crisis Working Paper Series, International Peace Academy.

Karol, D. \& Miguel, E. (2007). The electoral cost of war: Iraq casualties and the 2004 U.S. presidential election. Journal of Politics, 69(3), 631-646.

Krueger, A., \& Maleckova, J. (2003). Education, poverty and terrorism: is there a causal connection? Journal of Economic Perspectives, 17(4), 119-144.

Laayouni, H., Calafell, F., \& Bertranpetit, J. (2010). A genome-wide survey does not show the genetic distinctiveness of Basques. Human Genetics, 127(4), 455-458.

Laitin, D. D. (2000). Language conflict and violence: the straw that strengthens the camel's back. European Journal of Sociology, 41(1), 97-137.

Montalvo, J. G., \& Reynal-Querol, M. (2005). Ethnic polarization, potential conflict, and civil wars. American Economic Review, 95(3). 796-816.

Martín-Peña, J., Rodríguez-Carballeira, A., Escartín Solanelles, J., Porrúa García, C., \& Winkel, F. W. (2010). Strategies of psychological terrorism perpetrated by ETA's network. Psicothema, 22(1), 112-117.

Piazza, J. A. (2006). Rooted in poverty?: terrorism, poor economic development, and social cleavages. Terrorism and Political Violence, 18(1), 159-177.

Reynal-Querol, M. (2002). Ethnicity, political systems, and civil wars. Journal of Conflict Resolution, 46(1), 29-54. Reynal-Querol, M. (2002). Political systems, stability and civil wars. Defense and Peace Economics, 13(6), pp. 29-54.

Sen, A. (2008). Violence, identity and poverty. Journal of Peace Research, 45(1), 5-15.

UNICEF. (2000). The two faces of education in ethnic conflict: towards a peace building education for children, edited by Kenneth, D. B., \& Saltarelli, D., Innocenti Research Centre, Florence, Italy.

Wimmer, A., \& Cederman, L.-E. (2009). Ethnic politics and armed conflict: a configurational analysis of a new global data set. American Sociological Review, 74(2), 316-337. 
Table 1 Left/Right vs. Nationalist/Non-Nationalist

\begin{tabular}{lll}
\hline & Left & Right \\
\hline \multirow{2}{*}{ Nationalist } & Herri Batasuna (HB) & Partido Nacionalista Vasco (PNV) \\
& Eusko Alkartasuna (EA) & \\
& Aralar & \\
& $25.79 \%$ & $25.38 \%$ \\
\hline \multirow{2}{*}{ Non-Nationalist } & Partido Socialista Obrero Español (PSOE) & Partido Popular (PP) \\
& Izquierda Unida (IU) & Centro Democrático y Social (CDS) \\
& $32.53 \%$ & $16.30 \%$
\end{tabular}

Aggregate vote shares for the Basque Country. 1993 General Elections. 
Table 2 Summary Statistics

\begin{tabular}{|c|c|c|c|c|c|}
\hline Variable & \# Observations & Mean & Std. Dev. & Min & $\operatorname{Max}$ \\
\hline Assassinations & 7000 & 0.05 & 0.36 & 0 & 8 \\
\hline Conflict Index / 1000 people $(h=10 \mathrm{~km})$ & 7000 & 0.02 & 0.08 & 0 & 1.56 \\
\hline Conflict Index / 1000 people $(h=20 \mathrm{~km})$ & 7000 & 0.07 & 0.23 & 0 & 4.61 \\
\hline Population & 7000 & 8460.86 & 30569.95 & 78 & 393821 \\
\hline Polarization Mother Tongue & 5250 & 0.48 & 0.34 & 0 & 1 \\
\hline Mother Tongue Basque & 5250 & 1696.80 & 3371.67 & 0 & 37076 \\
\hline Mother Tongue Spanish & 5250 & 6236.34 & 26899.92 & 0 & 343127 \\
\hline Mother Tongue Both & 5250 & 339.88 & 1218.51 & 0 & 14734 \\
\hline Mother Tongue Other & 5250 & 149.56 & 634.61 & 0 & 10517 \\
\hline Polarization Language used at home & 4000 & 0.49 & 0.34 & 0 & 1 \\
\hline Language used at home Basque & 4000 & 1138.22 & 2045.16 & 0 & 20456 \\
\hline Language used at home Spanish & 4000 & 6499.02 & 27704.99 & 0 & 347335 \\
\hline Language used at home Both & 4000 & 705.63 & 1885.59 & 0 & 21172 \\
\hline Language used at home other & 4000 & 57.67 & 244.13 & 0 & 4035 \\
\hline Polarization Basque Knowledge & 6500 & 0.51 & 0.34 & 0 & 1 \\
\hline Basque Speakers & 6500 & 2372.77 & 5547.41 & 0 & 83354 \\
\hline Almost Basque Speakers & 6500 & 1620.93 & 6738.34 & 0 & 91204 \\
\hline Non-Basque Speakers & 6500 & 4270.79 & 19203.79 & 0 & 301430 \\
\hline Political Polarization & 4969 & 0.75 & 0.08 & 0.34 & 1 \\
\hline Left/Right Polarization & 4969 & 0.88 & 0.14 & 0.3 & 1 \\
\hline Nationalist/Non-Nationalist Polarization & 4969 & 0.75 & 0.26 & 0 & 1 \\
\hline Political Fractionalization & 4969 & 0.7 & 0.11 & 0.17 & 0.99 \\
\hline Number of votes & 4969 & 4870.82 & 17975.01 & 2 & 225279 \\
\hline PSOE votes & 5000 & 1165.13 & 4665.82 & 0 & 72055 \\
\hline $\mathrm{PP}$ votes & 5000 & 856.41 & 4420.19 & 0 & 69648 \\
\hline IU votes & 5000 & 304.86 & 1350.44 & 0 & 21148 \\
\hline PNV votes & 5000 & 1295.53 & 4558.58 & 0 & 71736 \\
\hline $\mathrm{HB}$ votes & 5000 & 377.11 & 1419.54 & 0 & 23727 \\
\hline EA votes & 5000 & 395.31 & 1188.77 & 0 & 17204 \\
\hline UCD votes & 5000 & 38.21 & 341.7 & 0 & 7589 \\
\hline Aralar votes & 5000 & 36.63 & 211.8 & 0 & 4495 \\
\hline Fraction of Population with academic degree & 5250 & 0.06 & 0.04 & 0 & 0.28 \\
\hline Unemployment Rate & 3984 & 0.15 & 0.06 & 0 & 0.36 \\
\hline Number of financial institutions / 1000 people & 5621 & 1.05 & 1.46 & 0 & 14.31 \\
\hline
\end{tabular}


Table 3 Baseline regressions

\begin{tabular}{|c|c|c|c|c|c|c|}
\hline & (1) & $(2)$ & $(3)$ & (4) & $(5)$ & $(6)$ \\
\hline Conflict index at t-1 & & $\begin{array}{c}0.109 * * * \\
(0.0154)\end{array}$ & $\begin{array}{l}0.223^{* * *} \\
(0.0163)\end{array}$ & $\begin{array}{l}0.248^{* * *} \\
(0.0177)\end{array}$ & $\begin{array}{l}0.238^{* * *} \\
(0.0197)\end{array}$ & $\begin{array}{l}0.248^{* * *} \\
(0.0161)\end{array}$ \\
\hline Conflict index at t-2 & & & $\begin{array}{c}-0.0768^{* * *} \\
(0.0173)\end{array}$ & $\begin{array}{c}-0.0558 * * * \\
(0.0179)\end{array}$ & $\begin{array}{c}-0.0618^{* * *} \\
(0.0157)\end{array}$ & $\begin{array}{c}-0.0399 * * \\
(0.0157)\end{array}$ \\
\hline Conflict index at t-3 & & & $\begin{array}{c}0.0308 \\
(0.0277)\end{array}$ & $\begin{array}{c}0.0371 \\
(0.0275)\end{array}$ & $\begin{array}{c}0.0126 \\
(0.0231)\end{array}$ & $\begin{array}{c}0.0376 \\
(0.0251)\end{array}$ \\
\hline Linguistic Polarization & $\begin{array}{l}-0.0141^{*} \\
(0.00773)\end{array}$ & $\begin{array}{l}-0.0132^{*} \\
(0.00722)\end{array}$ & $\begin{array}{c}-0.0977^{* * *} \\
(0.0224)\end{array}$ & $\begin{array}{c}-0.0239 * * * \\
(0.00631)\end{array}$ & $\begin{array}{c}-0.0331^{* * *} \\
(0.00762)\end{array}$ & $\begin{array}{c}-0.0338 * * * \\
(0.0114)\end{array}$ \\
\hline Political Polarization & $\begin{array}{c}0.0180 \\
(0.0335)\end{array}$ & $\begin{array}{c}0.0131 \\
(0.0311)\end{array}$ & $\begin{array}{c}0.0259 \\
(0.0726)\end{array}$ & $\begin{array}{l}0.0644^{*} \\
(0.0363)\end{array}$ & & \\
\hline $\begin{array}{l}\text { Political Polarization } \\
\text { (Left/Right) }\end{array}$ & & & & & $\begin{array}{c}0.0948 * * * \\
(0.0240)\end{array}$ & \\
\hline $\begin{array}{l}\text { Political Polarization } \\
\text { (Nationalist/Non-Nationalist) }\end{array}$ & & & & & $\begin{array}{c}-0.0304^{* *} \\
(0.0145)\end{array}$ & \\
\hline Political Fractionalization & & & & & & $\begin{array}{c}-0.154^{* * *} \\
(0.0497)\end{array}$ \\
\hline Constant & $\begin{array}{l}0.00399 \\
(0.0233)\end{array}$ & $\begin{array}{l}0.00599 \\
(0.0217)\end{array}$ & $\begin{array}{r}-0.351^{*} \\
(0.194)\end{array}$ & $\begin{array}{c}0.162^{*} \\
(0.0962)\end{array}$ & $\begin{array}{l}-0.188 \\
(0.158)\end{array}$ & $\begin{array}{c}0.612^{* * *} \\
(0.157)\end{array}$ \\
\hline First order autocorrelation & & & $-2.8474^{* * *}$ & $-2.8471^{* * *}$ & $-2.8658 * * *$ & $-2.8904^{* * *}$ \\
\hline Second order autocorrelation & & & -1.0384 & -1.2871 & -1.4855 & -1.2113 \\
\hline Observations & 4,469 & 4,469 & 4,469 & 4,469 & 4,469 & 4,469 \\
\hline Number of Municipalities & 250 & 250 & 250 & 250 & 250 & 250 \\
\hline
\end{tabular}

Robust standard errors in parentheses. ${ }^{* * *} \mathrm{p}<0.01,{ }^{* *} \mathrm{p}<0.05,{ }^{*} \mathrm{p}<0.1$. All columns include period-specific dummies. First and second order autocorrelation tests of residuals in the differenced model. 
Table 4 Other Covariates / Political Polarization

\begin{tabular}{|c|c|c|c|c|c|}
\hline & $(1)$ & $(2)$ & $(3)$ & $(4)$ & $(5)$ \\
\hline Conflict index at t-1 & $\begin{array}{r}0.238^{* * *} \\
(0.0297)\end{array}$ & $\begin{array}{r}0.225^{* * *} \\
(0.0187)\end{array}$ & $\begin{array}{r}0.234^{* * *} \\
(0.0191)\end{array}$ & $\begin{array}{l}0.237 * * * \\
(0.0201)\end{array}$ & $\begin{array}{r}0.219^{* * *} \\
(0.0200)\end{array}$ \\
\hline Conflict index at t-2 & $\begin{array}{c}-0.0641^{* * *} \\
(0.0156)\end{array}$ & $\begin{array}{c}-0.0702^{* * *} \\
(0.0156)\end{array}$ & $\begin{array}{c}-0.0644^{* * *} \\
(0.0146)\end{array}$ & $\begin{array}{c}-0.0643^{* * *} \\
(0.0145)\end{array}$ & $\begin{array}{c}-0.0785^{* * *} \\
(0.0150)\end{array}$ \\
\hline Conflict index at t-3 & $\begin{array}{c}0.0137 \\
(0.0216)\end{array}$ & $\begin{array}{l}0.00469 \\
(0.0240)\end{array}$ & $\begin{array}{l}0.00832 \\
(0.0235)\end{array}$ & $\begin{array}{c}0.0136 \\
(0.0235)\end{array}$ & $\begin{array}{c}-0.000347 \\
(0.0239)\end{array}$ \\
\hline Linguistic Polarization & $\begin{array}{c}-0.0248^{* * *} \\
(0.00724)\end{array}$ & $\begin{array}{c}-0.0314^{* * *} \\
(0.00804)\end{array}$ & $\begin{array}{c}-0.0444^{* * *} \\
(0.00921)\end{array}$ & $\begin{array}{c}-0.0337 * * * \\
(0.00874)\end{array}$ & $\begin{array}{r}-0.0191^{* *} \\
(0.00824)\end{array}$ \\
\hline $\begin{array}{l}\text { Political Polarization } \\
\text { (Left/Right) }\end{array}$ & $\begin{array}{c}0.0958^{* * *} \\
(0.0275)\end{array}$ & $\begin{array}{c}0.0659^{* * *} \\
(0.0209)\end{array}$ & $\begin{array}{c}0.0729^{* * *} \\
(0.0235)\end{array}$ & $\begin{array}{c}0.0747^{* * *} \\
(0.0230)\end{array}$ & $\begin{array}{c}0.0659^{* *} \\
(0.0303)\end{array}$ \\
\hline $\begin{array}{l}\text { Political Polarization } \\
\text { (Nationalist/Non-Nationalist) }\end{array}$ & $\begin{array}{r}-0.0261^{*} \\
(0.0141)\end{array}$ & $\begin{array}{l}-0.0242^{*} \\
(0.0133)\end{array}$ & $\begin{array}{c}-0.0254^{*} \\
(0.0151)\end{array}$ & $\begin{array}{r}-0.0246^{*} \\
(0.0138)\end{array}$ & $\begin{array}{l}-0.0198 \\
(0.0126)\end{array}$ \\
\hline Population (in thousands) & $\begin{array}{l}-0.0783 \\
(0.0541)\end{array}$ & & & & $\begin{array}{l}-0.0558 \\
(0.0559)\end{array}$ \\
\hline $\begin{array}{l}\text { Fraction of people with academic degree } \\
\quad \text { (per thousand people) }\end{array}$ & & $\begin{array}{c}-0.429^{* * *} \\
(0.151)\end{array}$ & & & $\begin{array}{c}-0.509 * * * \\
(0.176)\end{array}$ \\
\hline Unemployment rate & & & $\begin{array}{c}0.106 \\
(0.149)\end{array}$ & & \\
\hline $\begin{array}{l}\text { Number of financial establishments } \\
\text { (per thousand people) }\end{array}$ & & & & $\begin{array}{l}-0.00208 \\
(0.00158)\end{array}$ & $\begin{array}{c}-0.00531^{* *} \\
(0.00226)\end{array}$ \\
\hline Constant & $\begin{array}{l}0.0359 \\
(0.148)\end{array}$ & $\begin{array}{c}-1.188^{* * * *} \\
(0.458)\end{array}$ & $\begin{array}{l}-0.664 \\
(0.970)\end{array}$ & $\begin{array}{c}-0.000228 \\
(0.178)\end{array}$ & $\begin{array}{c}-1.058^{* *} \\
(0.512)\end{array}$ \\
\hline First order autorcorrelation & $-2.8352^{* * *}$ & $-2.8649 * * *$ & $-2.8592^{* * *}$ & $-2.8678^{* * *}$ & $-2.8635^{* * *}$ \\
\hline Second order autocorrelation & -1.3711 & -1.4959 & -1.5886 & -1.4109 & -1.4231 \\
\hline Observations & 4,469 & 4,469 & 3,969 & 4,444 & 4,444 \\
\hline Number of Municipalities & 250 & 250 & 250 & 249 & 249 \\
\hline
\end{tabular}

Robust standard errors in parentheses. ${ }^{* * *} \mathrm{p}<0.01,{ }^{* *} \mathrm{p}<0.05,{ }^{*} \mathrm{p}<0.1$. All columns include period-specific dummies. First and second order autocorrelation tests of residuals in the differenced model. 
Table 5 Other Covariates / Political Fractionalization

\begin{tabular}{|c|c|c|c|c|c|}
\hline & (1) & $(2)$ & $(3)$ & $(4)$ & $(5)$ \\
\hline Conflict index at t-1 & $\begin{array}{c}0.241^{* * *} \\
(0.0136)\end{array}$ & $\begin{array}{c}0.230^{* * *} \\
(0.0155)\end{array}$ & $\begin{array}{c}0.236^{* * *} \\
(0.0176)\end{array}$ & $\begin{array}{c}0.238^{* * *} \\
(0.0172)\end{array}$ & $\begin{array}{c}0.206^{* * *} \\
(0.0162)\end{array}$ \\
\hline Conflict index at t-2 & $\begin{array}{c}-0.0437^{* * *} \\
(0.0137)\end{array}$ & $\begin{array}{c}-0.0523^{* * *} \\
(0.0154)\end{array}$ & $\begin{array}{c}-0.0470 * * * \\
(0.0144)\end{array}$ & $\begin{array}{c}-0.0465^{* * *} \\
(0.0142)\end{array}$ & $\begin{array}{c}-0.0693 * * * \\
(0.0161)\end{array}$ \\
\hline Conflict index at t-3 & $\begin{array}{c}0.0285 \\
(0.0221)\end{array}$ & $\begin{array}{c}0.0226 \\
(0.0230)\end{array}$ & $\begin{array}{c}0.0221 \\
(0.0212)\end{array}$ & $\begin{array}{c}0.0264 \\
(0.0220)\end{array}$ & $\begin{array}{l}0.00486 \\
(0.0238)\end{array}$ \\
\hline Linguistic Polarization & $\begin{array}{c}-0.0366^{* * *} \\
(0.00977)\end{array}$ & $\begin{array}{c}-0.0322^{* * *} \\
(0.00969)\end{array}$ & $\begin{array}{c}-0.0539 * * * \\
(0.0139)\end{array}$ & $\begin{array}{c}-0.0249^{* * *} \\
(0.00883)\end{array}$ & $\begin{array}{c}-0.0389 * * * \\
(0.0150)\end{array}$ \\
\hline Political Fractionalization & $\begin{array}{c}-0.150 * * * \\
(0.0500)\end{array}$ & $\begin{array}{c}-0.144^{* * *} \\
(0.0489)\end{array}$ & $\begin{array}{c}-0.166^{* * *} \\
(0.0568)\end{array}$ & $\begin{array}{c}-0.156^{* * *} \\
(0.0511)\end{array}$ & $\begin{array}{c}-0.179 * * * \\
(0.0600)\end{array}$ \\
\hline Population (in thousands) & $\begin{array}{c}0.0139 \\
(0.0220)\end{array}$ & & & & $\begin{array}{c}0.0890 \\
(0.0641)\end{array}$ \\
\hline $\begin{array}{l}\text { Fraction of people with academic degree } \\
\quad \text { (per thousand people) }\end{array}$ & & $\begin{array}{c}-0.374^{* *} \\
(0.167)\end{array}$ & & & $\begin{array}{c}-0.982^{* * *} \\
(0.327)\end{array}$ \\
\hline Unemployment rate & & & $\begin{array}{l}0.203^{* *} \\
(0.0814)\end{array}$ & & $\begin{array}{c}0.0953 \\
(0.0938)\end{array}$ \\
\hline $\begin{array}{l}\text { Number of financial establishments } \\
\text { (per thousand people) }\end{array}$ & & & & $\begin{array}{c}-0.00678^{* * *} \\
(0.00207)\end{array}$ & $\begin{array}{c}-0.00964^{* * *} \\
(0.00348)\end{array}$ \\
\hline Constant & $\begin{array}{l}0.651^{* * *} \\
(0.206)\end{array}$ & $\begin{array}{l}-0.293 \\
(0.391)\end{array}$ & $\begin{array}{l}-0.457 \\
(0.503)\end{array}$ & $\begin{array}{c}0.951^{* * *} \\
(0.257)\end{array}$ & $\begin{array}{c}-2.605^{* * *} \\
(0.945)\end{array}$ \\
\hline First order autocorrelation & $-2.8966^{* * *}$ & $-2.888 * * *$ & $-2.8807^{* * *}$ & $-2.8917^{* * *}$ & $-2.8839 * * *$ \\
\hline Second order autocorrelation & -1.3579 & -1.3053 & -1.4128 & -1.2609 & -1.2289 \\
\hline Observations & 4,469 & 4,469 & 3,969 & 4,444 & 3,946 \\
\hline Number of Municipalities & 250 & 250 & 250 & 249 & 249 \\
\hline
\end{tabular}

Robust standard errors in parentheses. ${ }^{* * *} \mathrm{p}<0.01,{ }^{* *} \mathrm{p}<0.05,{ }^{*} \mathrm{p}<0.1$. All columns include period-specific dummies. First and second order autocorrelation tests of residuals in the differenced model. 
Table 6 Further Robustness Tests

\begin{tabular}{|c|c|c|c|c|c|}
\hline & $(1)$ & $(2)$ & $(3)$ & $(4)$ & $(5)$ \\
\hline Conflict index at t-1 & $\begin{array}{r}0.218^{* * *} \\
(0.0195)\end{array}$ & $\begin{array}{l}0.216^{* * *} \\
(0.0191)\end{array}$ & $\begin{array}{r}0.237^{* * *} \\
(0.0159)\end{array}$ & $\begin{array}{l}0.280^{* * *} \\
(0.0269)\end{array}$ & $\begin{array}{l}0.283^{* * *} \\
(0.0148)\end{array}$ \\
\hline Conflict index at t-2 & $\begin{array}{c}-0.0775^{* * *} \\
(0.0153)\end{array}$ & $\begin{array}{c}-0.0774^{* * *} \\
(0.0160)\end{array}$ & $\begin{array}{c}-0.0895^{* * *} \\
(0.0137)\end{array}$ & $\begin{array}{c}0.0441 \\
(0.0684)\end{array}$ & $\begin{array}{c}0.0462 \\
(0.0784)\end{array}$ \\
\hline Conflict index at t-3 & $\begin{array}{c}-0.000644 \\
(0.0240)\end{array}$ & $\begin{array}{c}0.000106 \\
(0.0255)\end{array}$ & $\begin{array}{c}0.0138 \\
(0.0301)\end{array}$ & & \\
\hline $\begin{array}{l}\text { Linguistic Polarization } \\
\text { (Basque Knowledge) }\end{array}$ & $\begin{array}{c}-0.0261^{* * *} \\
(0.00880)\end{array}$ & & & $\begin{array}{c}-0.0605^{* *} \\
(0.0265)\end{array}$ & $\begin{array}{r}-0.100 * * \\
(0.0398)\end{array}$ \\
\hline $\begin{array}{c}\text { Linguistic Polarization } \\
\text { (Mother Tongue) }\end{array}$ & & $\begin{array}{r}-0.0324^{*} \\
(0.0173)\end{array}$ & & & \\
\hline $\begin{array}{l}\text { Linguistic Polarization } \\
\text { (Language used at home) }\end{array}$ & & & $\begin{array}{c}-0.0522^{* *} \\
(0.0247)\end{array}$ & & \\
\hline $\begin{array}{l}\text { Political Polarization } \\
\text { (Left/Right) }\end{array}$ & $\begin{array}{c}0.0521^{* *} \\
(0.0225)\end{array}$ & $\begin{array}{c}0.0531^{* *} \\
(0.0227)\end{array}$ & $\begin{array}{c}0.0630^{* * *} \\
(0.0217)\end{array}$ & $\begin{array}{l}0.124^{* *} \\
(0.0527)\end{array}$ & \\
\hline $\begin{array}{l}\text { Political Polarization } \\
\text { (Nationalist/Non-Nationalist) }\end{array}$ & $\begin{array}{l}-0.0192 \\
(0.0126)\end{array}$ & $\begin{array}{c}-0.0289^{* *} \\
(0.0146)\end{array}$ & $\begin{array}{c}-0.0299 * * \\
(0.0151)\end{array}$ & $\begin{array}{c}-0.0882^{* * *} \\
(0.0254)\end{array}$ & \\
\hline Political Fractionalization & & & & & $\begin{array}{r}-0.129 * * \\
(0.0632)\end{array}$ \\
\hline $\begin{array}{l}\text { Fraction of people with academic degree } \\
\quad \text { (per thousand people) }\end{array}$ & $\begin{array}{c}-0.535 * * * \\
(0.165)\end{array}$ & $\begin{array}{c}-0.554^{* * *} \\
(0.183)\end{array}$ & $\begin{array}{c}-0.406^{* *} \\
(0.190)\end{array}$ & $\begin{array}{c}-1.304^{* * *} \\
(0.437)\end{array}$ & $\begin{array}{c}-1.542^{* *} \\
(0.627)\end{array}$ \\
\hline $\begin{array}{l}\text { Number of financial establishments } \\
\quad \text { (per thousand people) }\end{array}$ & $\begin{array}{c}-0.00557^{* * *} \\
(0.00214)\end{array}$ & $\begin{array}{c}-0.0104^{* * *} \\
(0.00355)\end{array}$ & $\begin{array}{c}-0.0115^{* * *} \\
(0.00380)\end{array}$ & & \\
\hline Constant & $\begin{array}{c}-1.202^{* * *} \\
(0.461)\end{array}$ & $\begin{array}{c}-1.334^{* *} \\
(0.578)\end{array}$ & $\begin{array}{l}-1.002 \\
(0.611)\end{array}$ & $\begin{array}{c}-2.499 \\
(1.533)\end{array}$ & $\begin{array}{l}-1.629 \\
(2.010)\end{array}$ \\
\hline First order autocorrelation & $-2.866^{* * *}$ & $-2.8654^{* * *}$ & $-2.8463^{* * *}$ & $-2.9455^{* * *}$ & $-2.9017^{* * *}$ \\
\hline Second order autocorrelation & -1.4319 & -1.3883 & -0.8221 & -1.0727 & -1.0509 \\
\hline Observations & 4,444 & 4,444 & 3,962 & 4,469 & 4,469 \\
\hline Number of Municipalities & 249 & 249 & 249 & 250 & 250 \\
\hline
\end{tabular}

Robust standard errors in parentheses. ${ }^{* * *} \mathrm{p}<0.01,{ }^{* *} \mathrm{p}<0.05,{ }^{*} \mathrm{p}<0.1$. All columns include period-specific dummies. First and second order autocorrelation tests of residuals in the differenced model. 
Table 7 Dates available and interpolated

\begin{tabular}{lll}
\hline Variable & Dates available & Interpolated sample \\
\hline & & \\
Terrorist assassinations & $1981-2008$ & {$[1981-2008]$} \\
Vote Shares & $1989,1993,1996,2000,2004,2008$ & {$[1989-2008]$} \\
Basque Knowledge & $1981,1986,1991,1996,2001,2006$ & {$[1981-2006]$} \\
Mother Tongue & $1986,1991,1996,2001,2006$ & {$[1986-2006]$} \\
Language Spoken at Home & $1991,1996,2001,2006$ & {$[1991-2006]$} \\
Population & $1981,1986,1991,1996,2001,2006-2008$ & {$[1981-2008]$} \\
Employed and Unemployed People & $1986,1991,1996,2001,2006$ & {$[1986-2006]$} \\
People with an academic degree & $1986,1991,1996,2001,2006$ & {$[1986-2006]$} \\
Number of financial Establishments & 1985,2007 & {$[1985-2007]$} \\
\hline
\end{tabular}




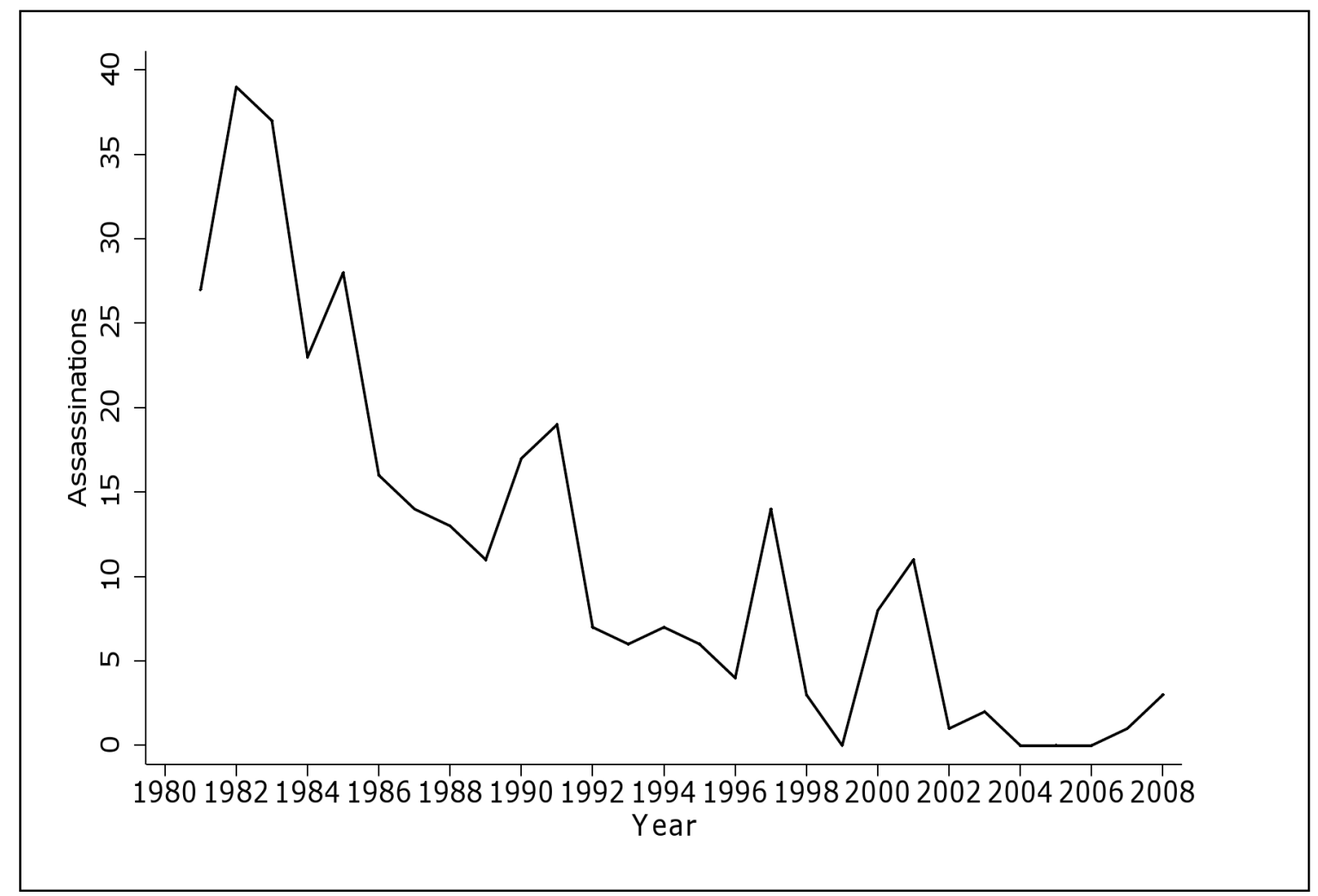

Fig. 1 Terrorist Assassinations in the Basque Country 


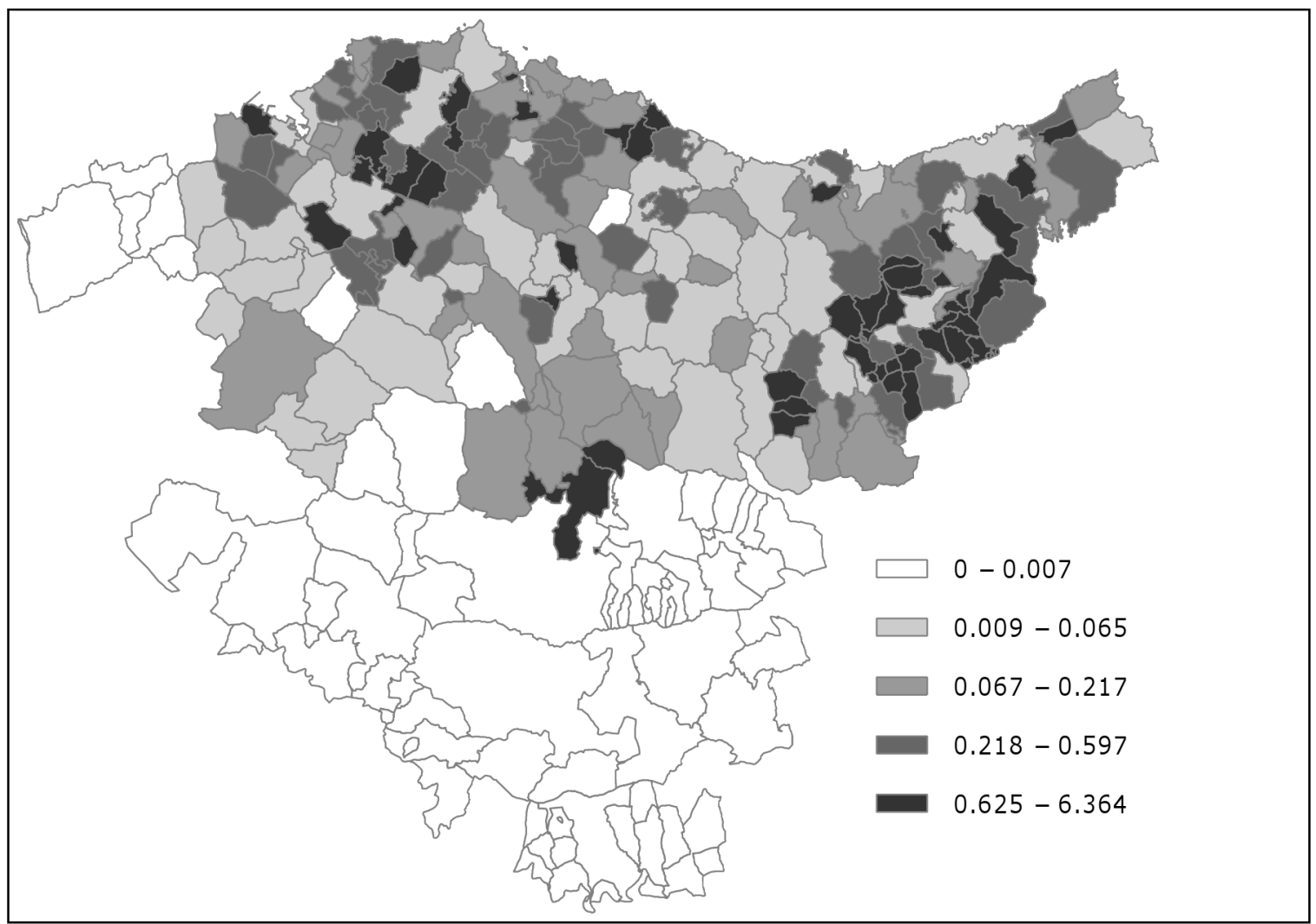

Fig. 2 This map shows Basque municipalities clasified into five quantiles according to the sum of the spatial conflict index over all time periods. 


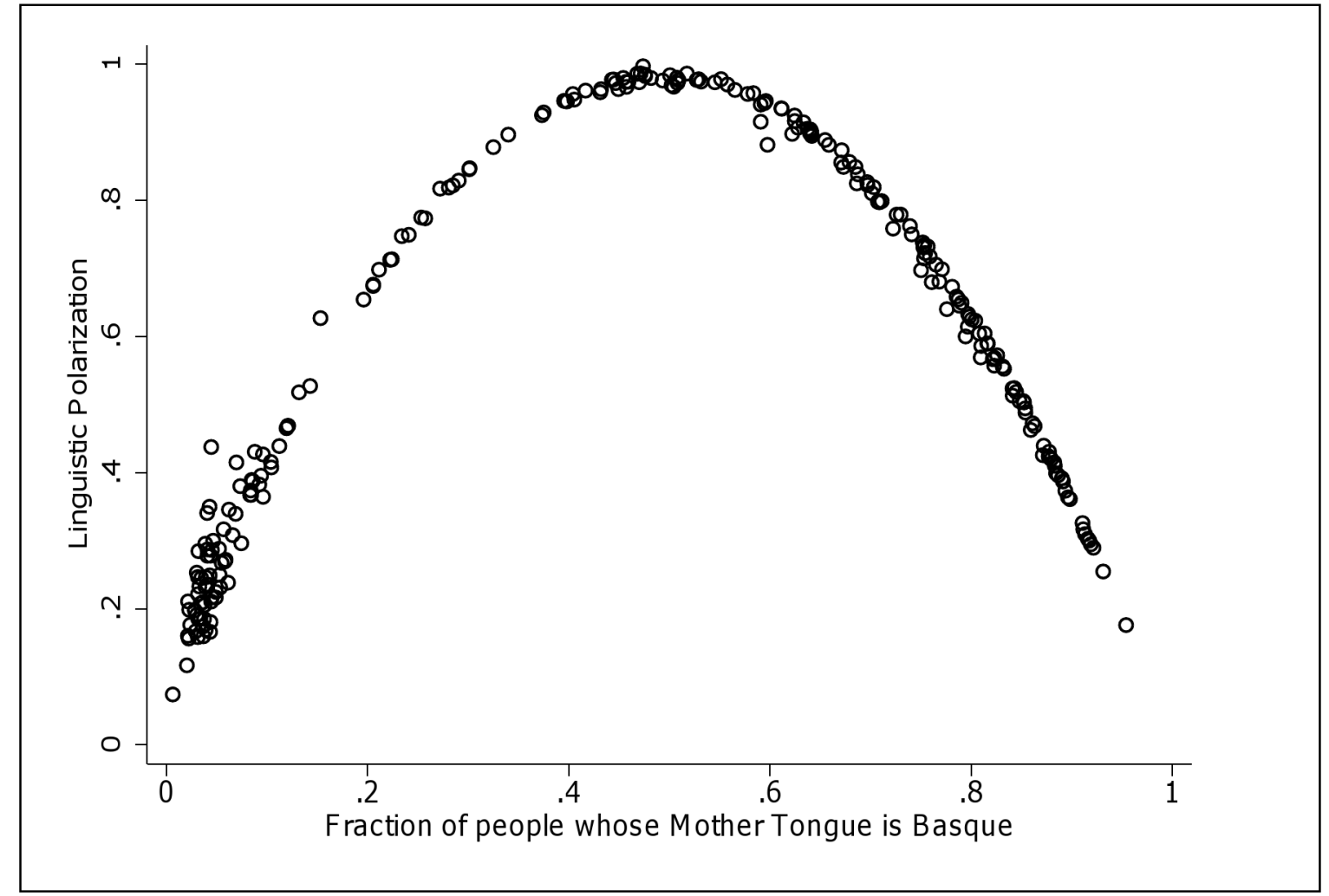

Fig. 3 Linguistic Polarization (Mother Tongue) as a function of the size of the Basque Mother Tongue linguistic group. Each circle corresponds to a municipality. Data correspond to year 2006 when polarization ranged from 0.07 to 1 . 


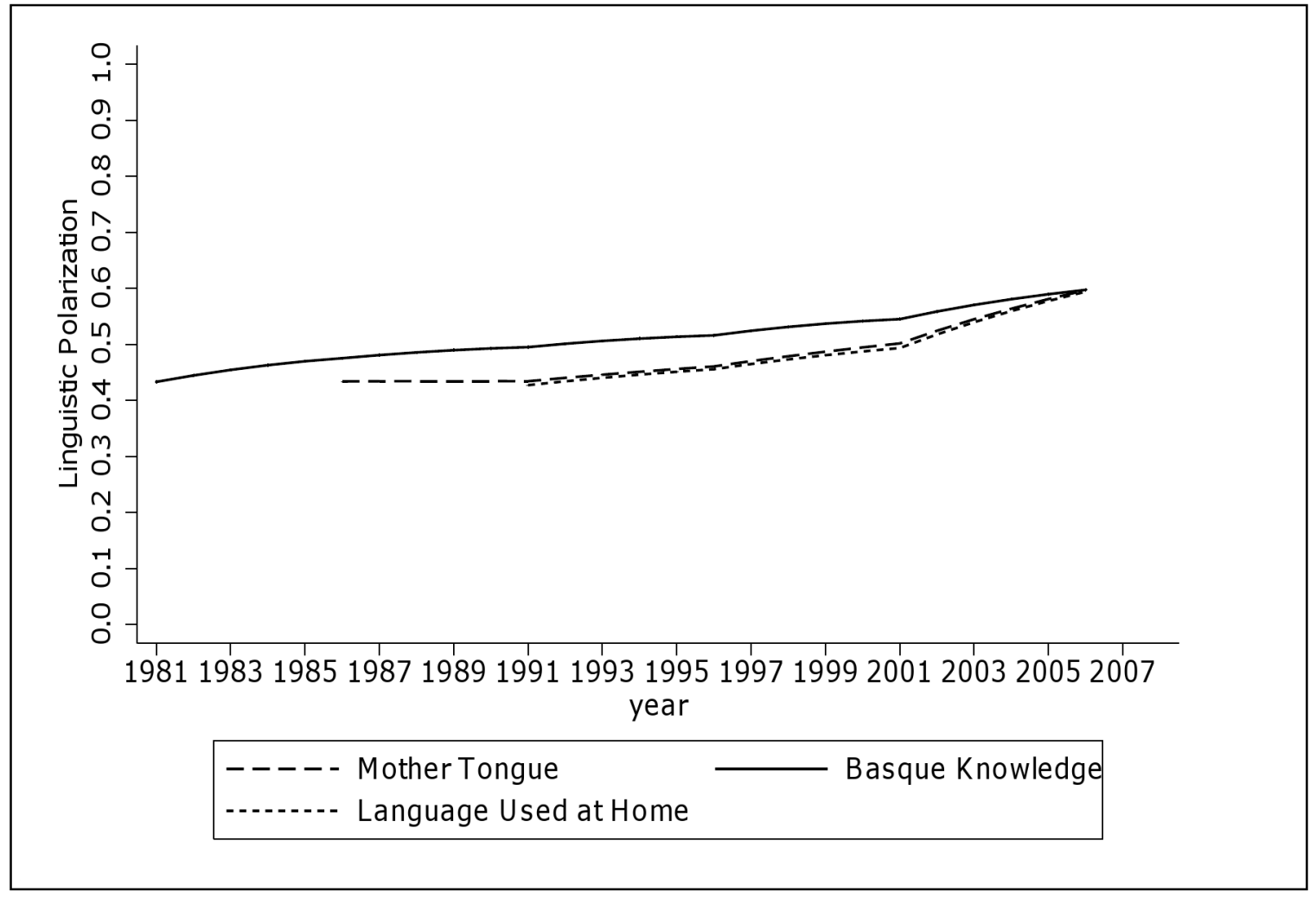

Fig. 4 Average Linguistic Polarization across Municipalities 


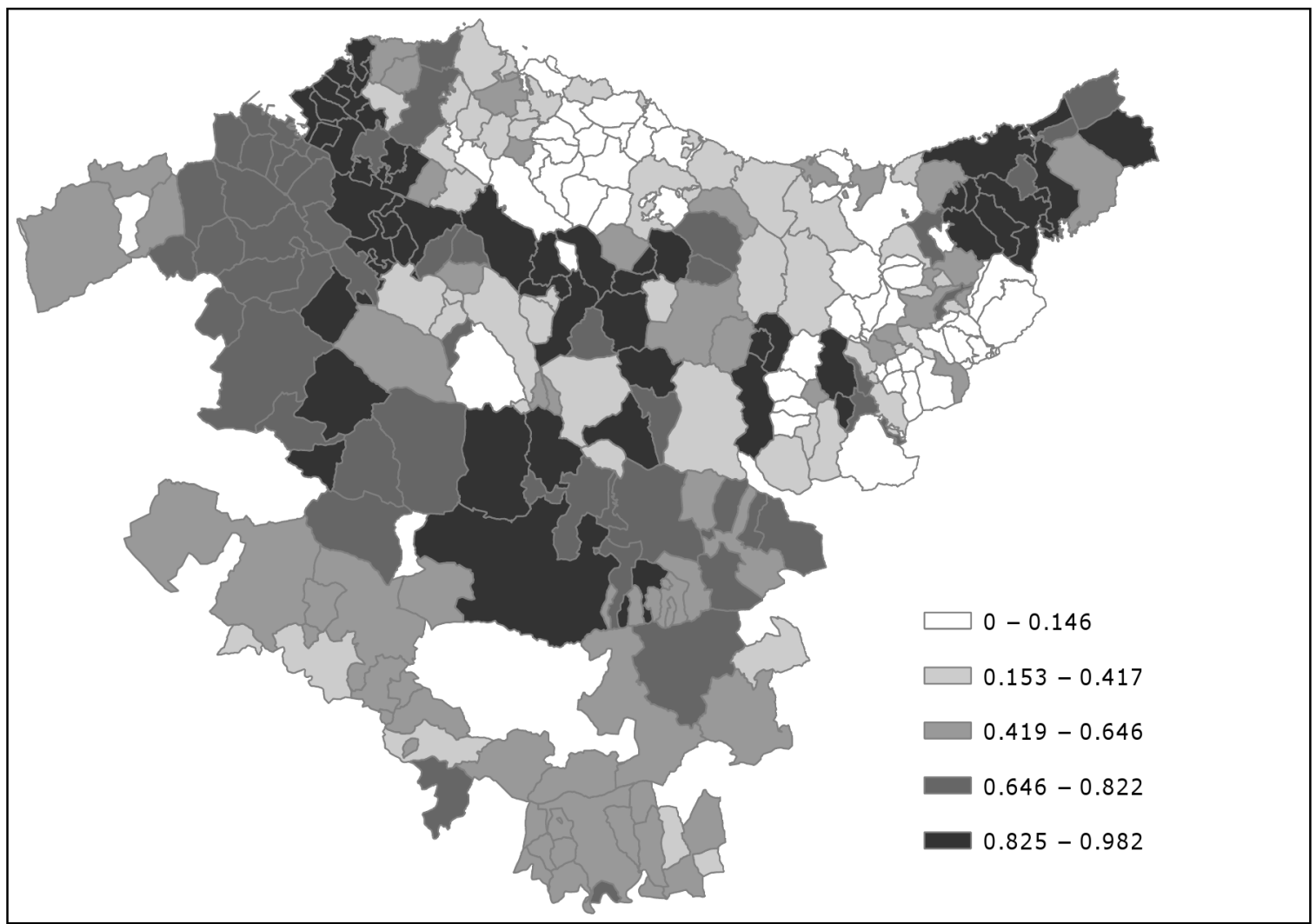

Fig. 5 This map shows Basque municipalities clasified into five quantiles according to their time average of linguistic polarization. 


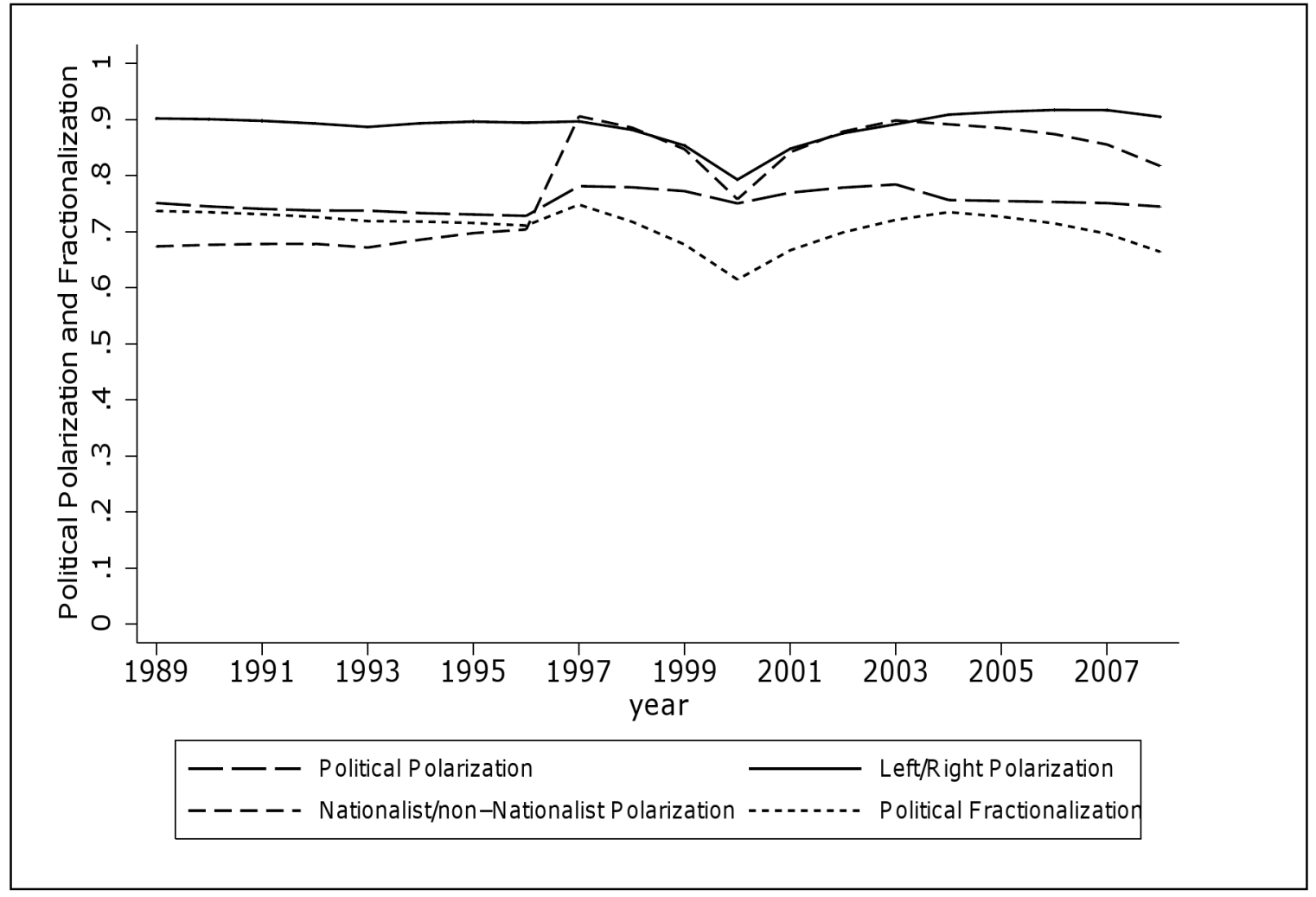

Fig. 6 Average Political Polarization and Fractionalization across municipalities. 


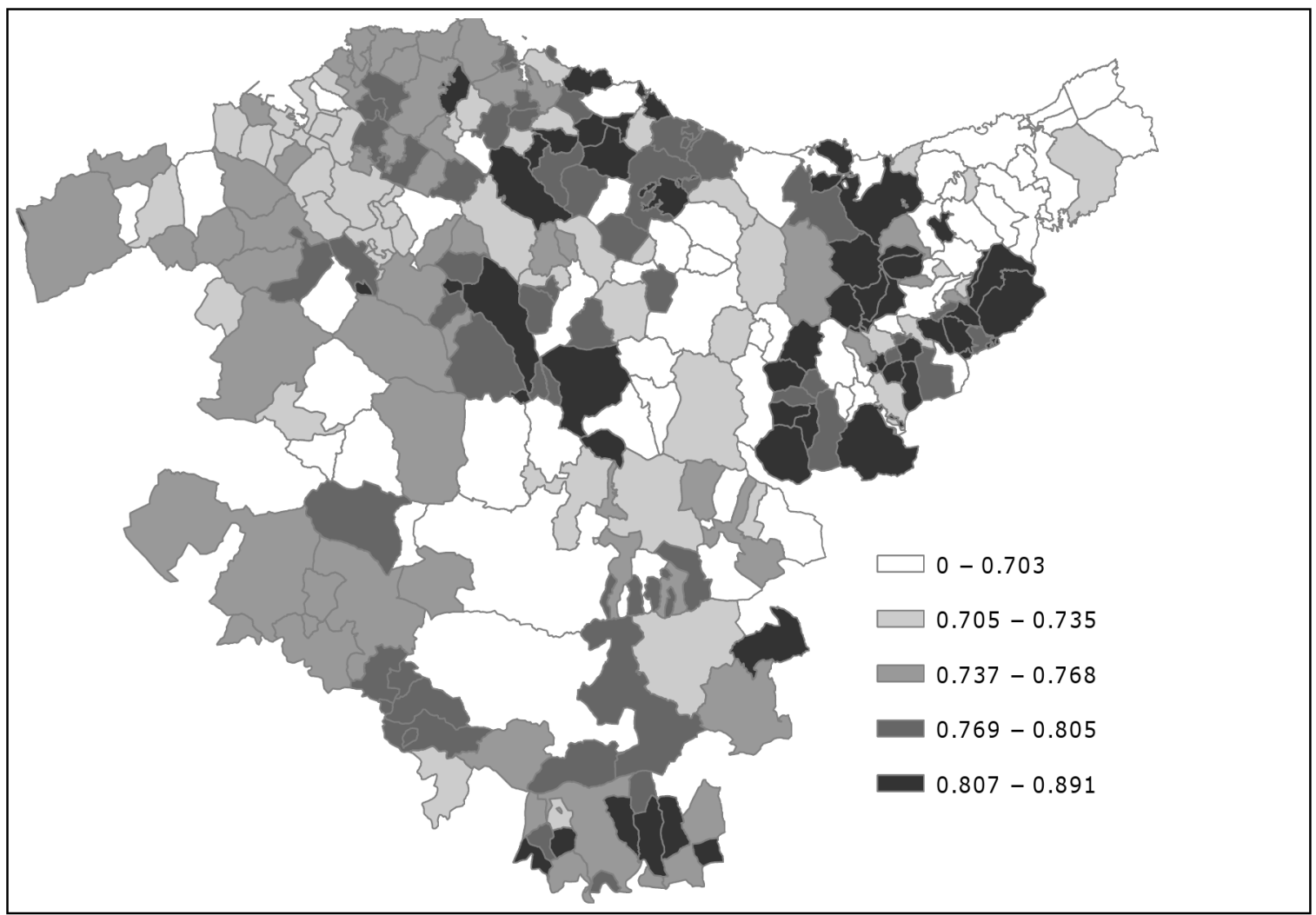

Fig. 7 This map shows Basque municipalities clasified into five quantiles according to their time average of political polarization. 